\title{
PRESERVING THE PHOTOGRAPHIC NEGATIVES OF HARRISON R. CRANDALL, OFFICIAL PHOTOGRAPHER OF The Grand Teton National PARK
}

\author{
KENNETH A. BARRICK $\downarrow$ GEOGRAPHY DEPARTMENT $\downarrow$ UNIVERSITY OF ALASKA FAIRBANKS
}

\begin{abstract}
A long time ago, in 1922 to be exact, a man and his young bride packed all their possessions into a Model $\mathrm{T}$ Ford truck, and navigated the primitive road eastward across Teton Pass. Harrison and Hildegard Crandall were undertaking an adventure to live out their American dream. They intended to raise a family in Jackson Hole, and interpret their "ideal landscape"-the Teton country-in oil paintings and photographs. Like so many energetic Americans before them, the Crandall family had the fortitude and perseverance to make their dreams come true. There were many tough years of dry homesteading in Jackson Hole, building and running an art business during the Great Depression, and weathering the controversies of frontier life during turbulent times. Nonetheless, the Crandall family successfully operated their art studio for 34 years near Jenny Lake in the Grand Teton National Park. They also operated a studio in the shadow of Jackson Lake Dam at the old village of Moran. Today, we can celebrate the Crandall family legacy by studying Harrison's many fine paintings and photographs that are found in collections and homes far and wide.
\end{abstract}

Harrison Crandall was "Official Photographer" of the Grand Teton National Park from the Park's establishment in 1929 until his retirement in the 1960s, which gave him a unique opportunity to photograph many early Park scenes. Thousands of photographic negatives were produced of Grand Teton landscapes, local ranch life, tourists, and officials. A customary part of any photographic business is to file all negatives in a safe place for future use. Harrison's irreplaceable negative archive had grown to fill several filing cabinets. However, the routine storage process was destined to become a legendary story filled with elements of photographic tragedy, insight and conservation.

On Christmas Eve 1954, Harrison's log studio-workshop building where the negatives were stored was mysteriously engulfed in fire. The studio was adjacent to the Crandall's home, which was located near Moose, Wyoming. The Crandalls their visiting daughter, Nancy, and her husband, Chuck Cooper, were to help celebrate the holiday with resident co-workers, Quita (Harrison's other daughter), and her husband, Herb Pownall. When the fire was discovered, fire fighters were summoned from Park Headquarters, which was located a few miles away at Moose. It took precious time for the responders to take drained and dry firefighting equipment from storage. Water was found for a pump truck in nearby Ditch Creek, but a thick layer of ice prevented quick access. There was too little time to save the burning structure, and only a small portion of the Crandall negative file could be rescued.

The aftermath of the studio-workshop fire was no time to grieve over the irreplaceable losses, which also included some of Harrison's oil paintings and camera equipment. The rescued negatives were soaked! Herb recognized that if the wet negatives were not immediately separated and dried, they would perish within a few days from physical and/or mildew damage. Herb understood the sensitivity of the negatives because he was a photographic expert himself, and worked for many years as Harrison's 
darkroom technician and studio manager. Harrison, Herb, and Chuck raced to separate the wet negatives and hang them in the air to dry. Hastily strung drying lines became a chaotic profusion of images. In the rush to save as many negatives as possible, some potentially salvageable images without identifying notes were lost in the charred ruins under foot. In all, about 1,200 negatives were rescued (mostly 3.25" $\mathrm{x}$ 4.25 " and a few 4.75" x 6.75").

Many rescued negatives were slightly damaged around the edges from partial melting of the plastic base and emulsion layers. Some negatives had minor warping and lifting of emulsion within the prime image area. Remarkably, most of the rescued images remained in somewhat useable condition. In the end, the surviving negatives were rescued thanks to the foresight and quick action of Harrison, and the dedicated assistance of other family members. The dried negatives were placed back into bulk storage where they rested for nearly half a century. Despite the heavy losses, Harrison remained undaunted. At the age of 67 , his vigorous constitution drove him to rebuild. Out of the ashes, he built a larger studioworkshop, and continued his life-long quest to create art and photographs of his favorite place on earth for show at his Jenny Lake studio.

The surviving Crandall negatives resurfaced during the "Creating a Vision of Grand Teton National Park" research project (see Barrick 2008, 2009). Initially, the study of Harrison Crandall's work involved locating photographic "prints" from private collections, the Grand Teton National Park archive, and the national archives. At the time, I did not fully understand the scope of the negative collection or the number of recorded subjects. Moreover, Herb initially underestimated the importance of the negatives for research because he believed that the fire damage made them very difficult to print using standard photographic technology. In fact, Herb tried to make some contact photographic prints years ago, but that project was abandoned, in part, due to the incredible amount of darkroom time that would have been required to avoid extreme handling damage and to print all of the images. In 2010, I was invited to visit the Pownalls in order to scan some Crandall prints, and during that process, Herb brought out a negative and showed it to me. I was pleasantly surprised to learn that the negative exhibited far less damage and warping than I expected. It was clear that digital scanning equipment would accommodate the negatives without causing further damage, and provide a high-quality digital image (in any event, the edges were likely to be cropped somewhat during most printing applications). Quita and Herb Pownall graciously agreed to allow me to digitally scan the surviving Crandall negatives for use in my research and publications. The digital negatives are easily converted to positive images using standard photographic editing software.

The rescued negatives had a storied history, but their journey was not yet complete! The digitization process opened up another important part of the story. The Pownalls, buoyed with a renewed sense of the historic and research value of the images, graciously decided to donate the negatives, and the digital copies, to the American people through the Grand Teton National Park archive. In a very real sense, the negatives were now destined to close a circle - a major visual archive of Harrison and Hildegard Crandall's life work, including images of the Grand Teton National Park's founding activities, was going to reside in perpetuity with the National Park that they loved. Moreover, since most future use of the images will be based on digital technology, the donated digital copies will help the Park conserve the images by reducing the need to handle the fragile negatives. Curator of the Grand Teton National Park, Alice Hart, arranged for funds to place the negatives in archival sleeves, and to include them in the National Park Service's photographic inventory system. The Crandall negatives are now in safe, permanent, temperature-controlled storage at the National Park Service's photographic archive facility at Tucson, Arizona.

The Crandall negatives were appraised by Terry Winchell of Fighting Bear Antiques (Jackson, Wyoming), in consultation with other experts that have evaluated the collected works of early western photographers. In 2011, the appraised value of the Crandall negative collection and associated digital scans was determined to be $\$ 185,000$. While the appraisal provided an expert assessment of the current "market" value of the donation, it is not customary for such appraisals to capture the considerable "nonmarket" value that is associated with historically important art collections. In nonmarket terms, it is fair to say that the negatives are now part of the priceless heritage of the American people. The negatives (and images they record) will provide an enduring benefit through their role in future research and interpretation of Grand Teton National Park. These nationally important images will be appreciated and remembered as a treasure that will be enjoyed by generations to come.

The following figures (1-20) are a selected sample of the images contained in the Crandall 
negative collection, which is now part of the Grand Teton National Park archive. The images speak for themselves.

\section{$\uparrow \quad$ ACKNOWLEDGEMENTS}

The Crandall research was graciously supported, assisted, and reviewed by Quita and Herb Pownall (Harrison Crandall's daughter and son-inlaw - both worked in Crandall Studios). The Curator of Grand Teton National Park supported the field and archive research. Valuable assistance was provided by the staff of the AMK Ranch and the University of Wyoming-National Park Research Center. The research was conducted under Grand Teton National Park research permit GRTE-2008-SCI-0067.

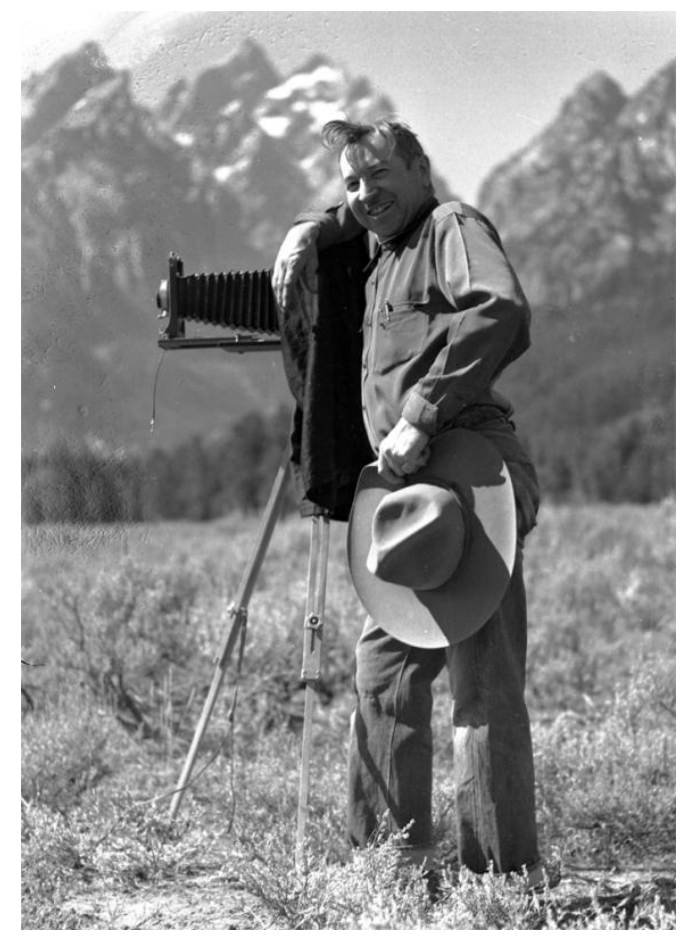

Figure 1. Harrison R. Crandall posing with his camera near the family homestead, now located in Grand Teton National Park (photo by Harrison R. Crandall, Grand Teton National Park archive).

\section{$\downarrow \quad$ Literature CiTED}

Barrick KA. 2008. Harrison R. Crandall: Artist, pioneer and patron of Grand Teton National Park. In: Harlow HJ , Harlow MA, editors. University of Wyoming-National Park Service Research Center, Grand Teton National Park, 30th Annual Report 2006 and 2007. 19-29.
Barrick KA. 2009. Creating a Vision of Grand Teton National Park-Preserving the Photographs of Harrison R. Crandall. In: Harlow HJ, Harlow MA, editors. University of Wyoming-National Park Service Research Center, Grand Teton National Park, 32nd Annual Report. pp15-20.

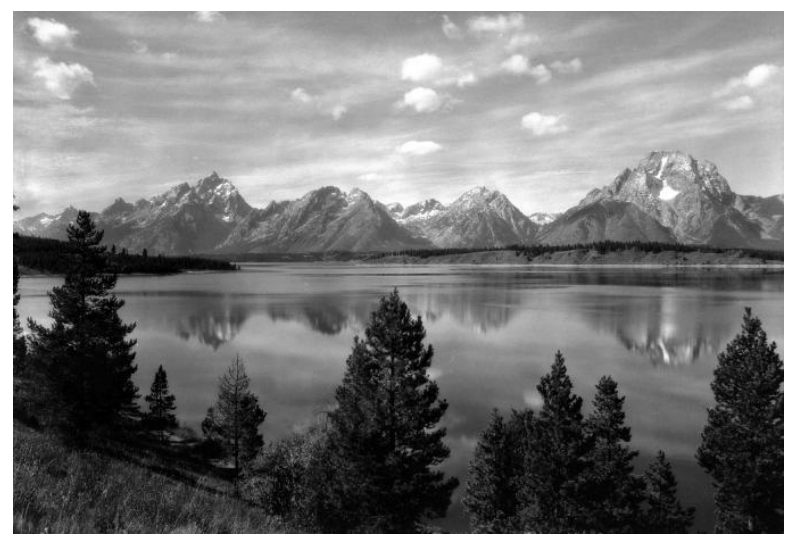

Figure 2. "Teton Range" \#1017 (photo by Harrison R. Crandall, Grand Teton National Park archive).

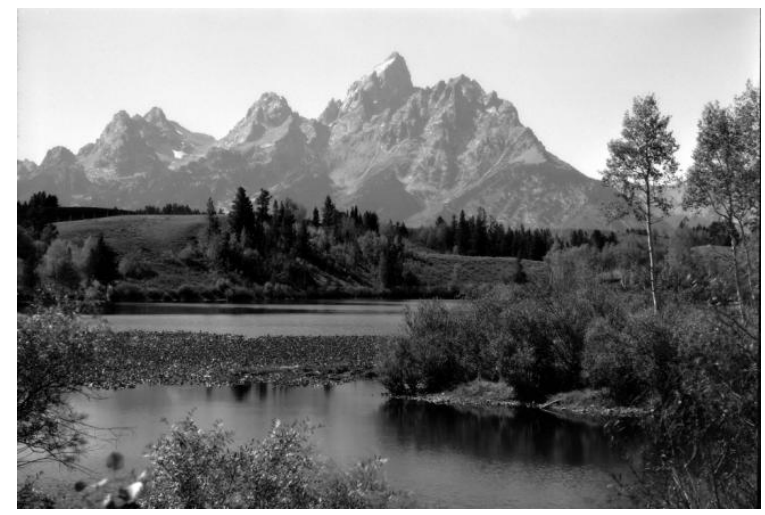

Figure 3. "Mirrored Granite Peaks" \#1095 (photo by Harrison R. Crandall, Grand Teton National Park archive).

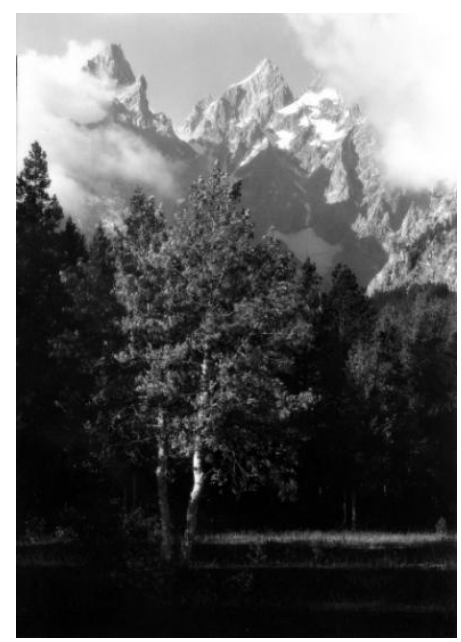

Figure 4. "Broken Fog" \#1034 (photo by Harrison R. Crandall, Grand Teton National Park archive). 


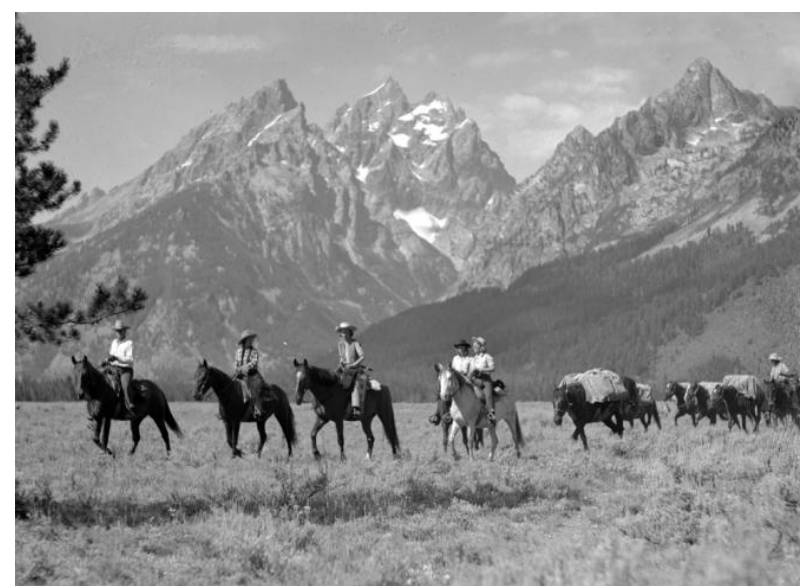

Figure 5. A pack train. (photo by Harrison R. Crandall, Grand Teton National Park archive).

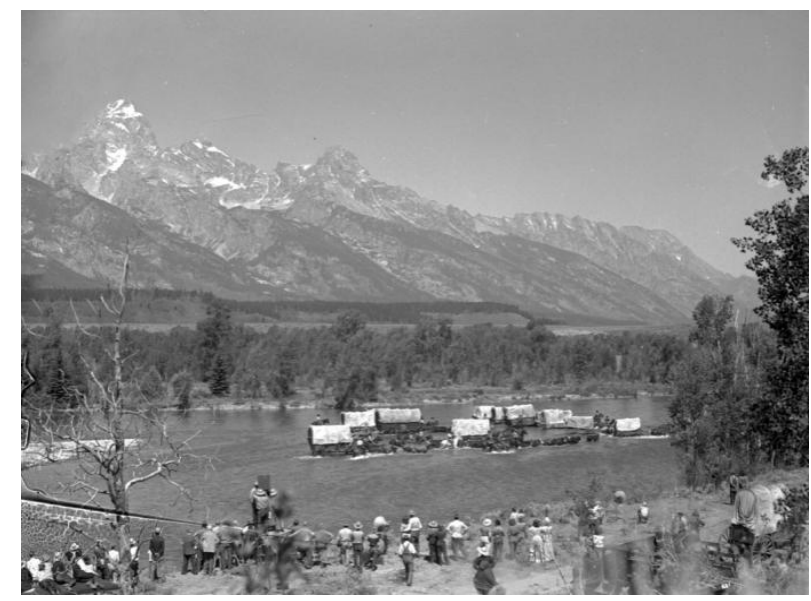

Figure 6. The set of a western-theme movie production in action (photo by Harrison R. Crandall, Grand Teton National Park archive).

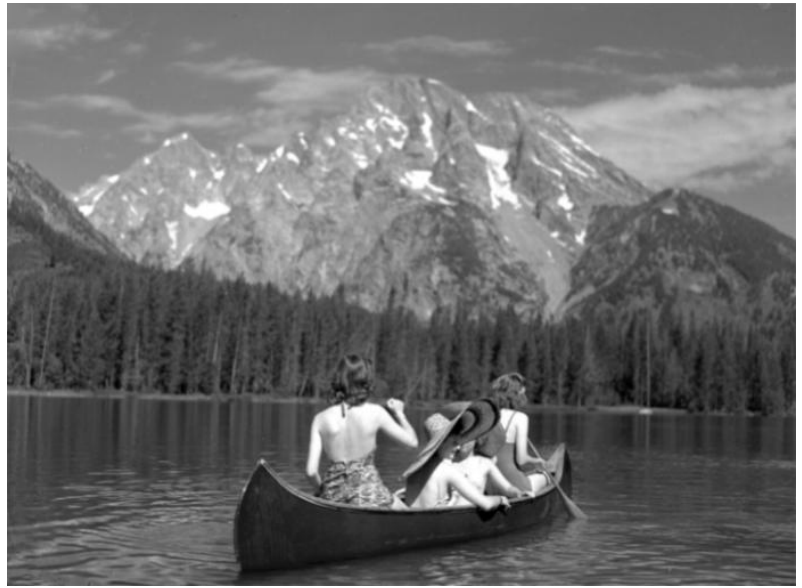

Figure 7. Canoeing on Jenny Lake (photo by Harrison R. Crandall, Grand Teton National Park archive).

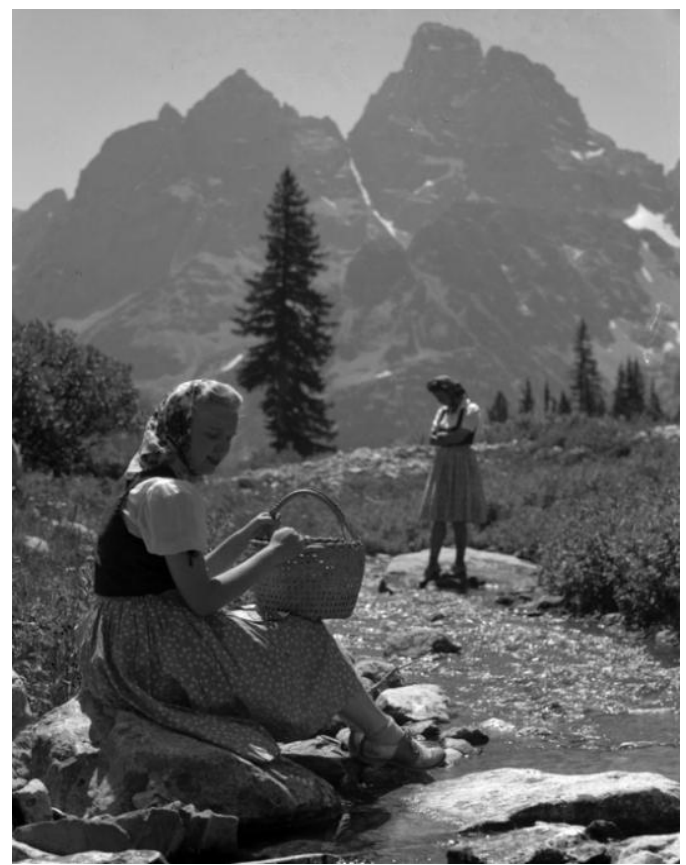

Figure 8. Among the Tetons (photo by Harrison R. Crandall, Grand Teton National Park archive).

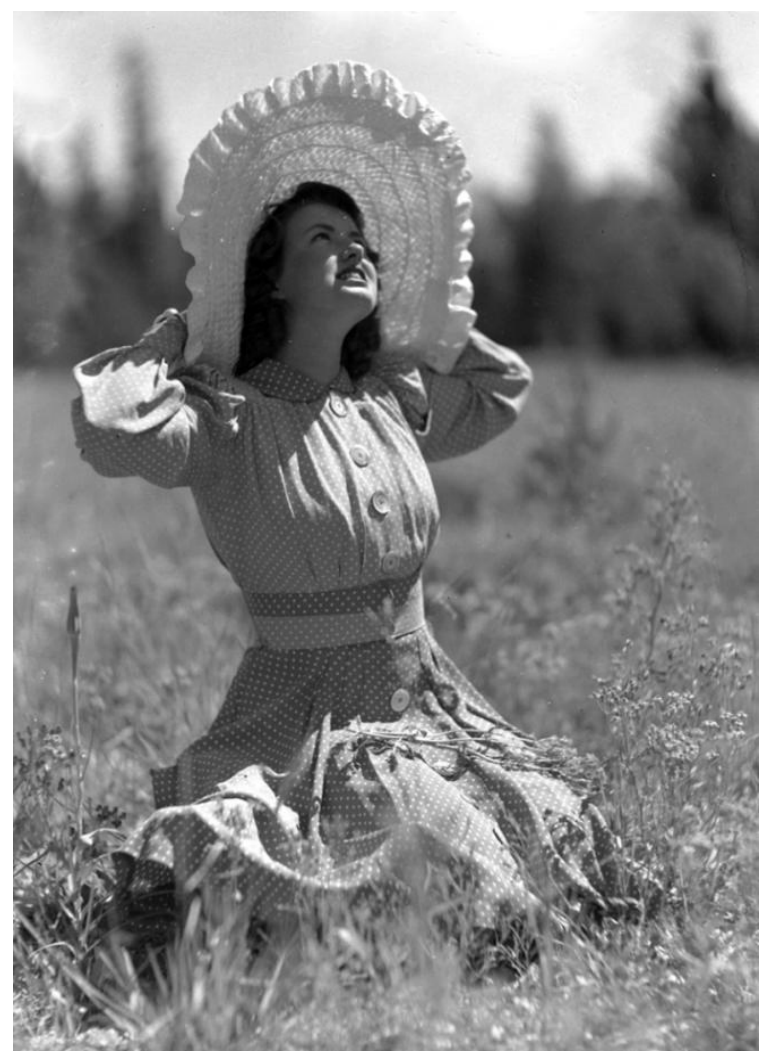

Figure 9. Margaret Smith (Craighead)-Harrison often asked local people to model in his staged photographshere among the wildflowers. (photo by Harrison R. Crandall, Grand Teton National Park archive). 


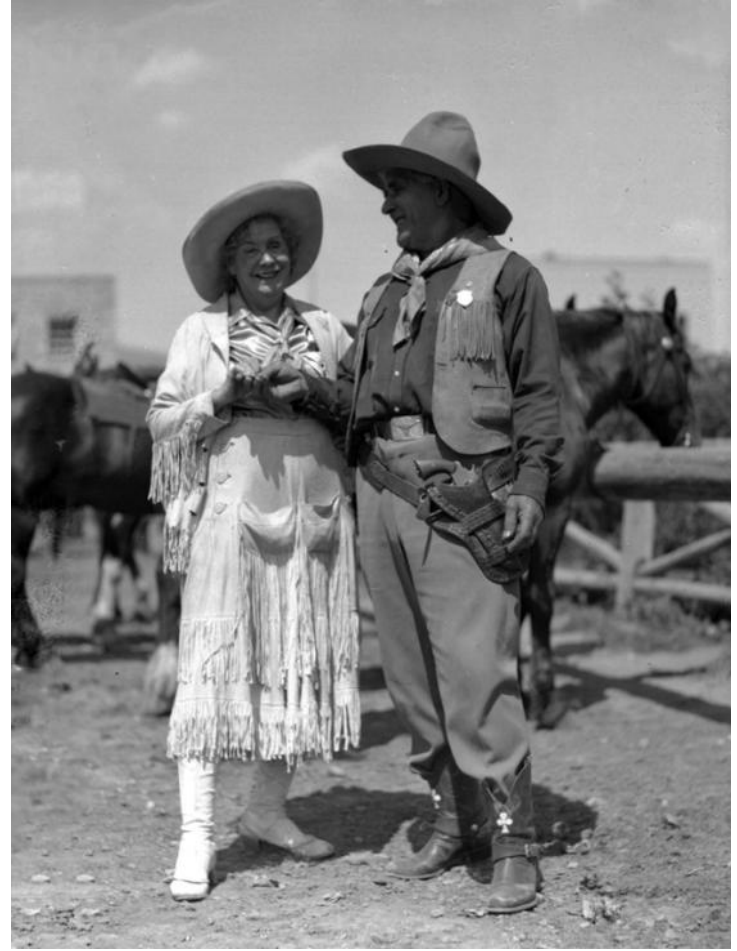

Figure 10. Tossing horseshoes at camp under the Tetons (photo by Harrison R. Crandall, Grand Teton National Park archive).

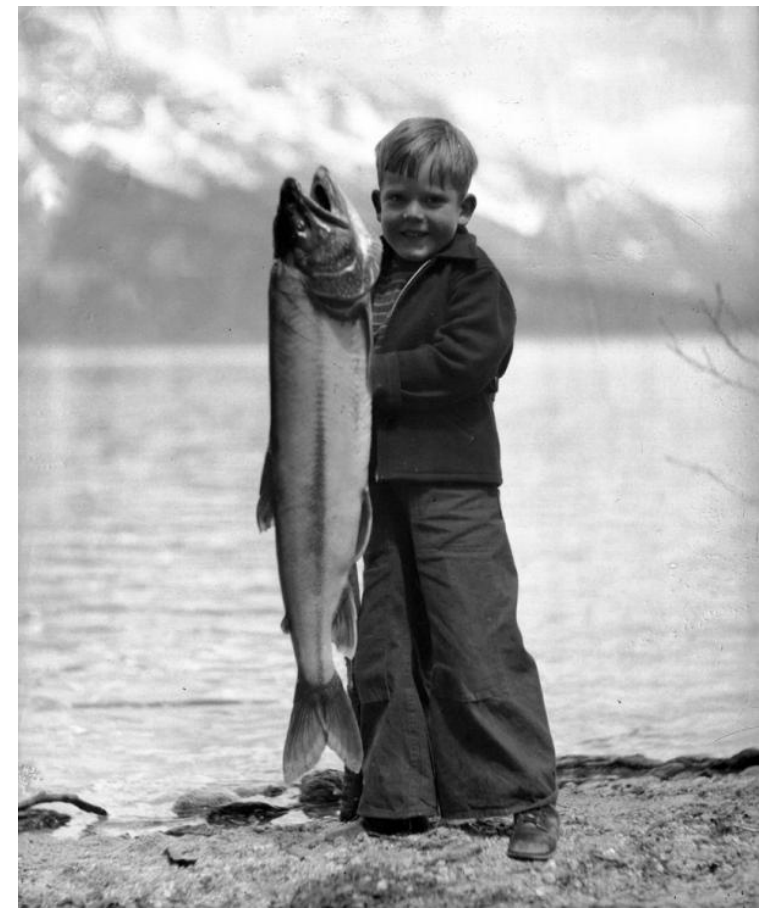

Figure 11. The big fish of Jackson Lake (photo by Harrison R. Crandall, Grand Teton National Park archive).

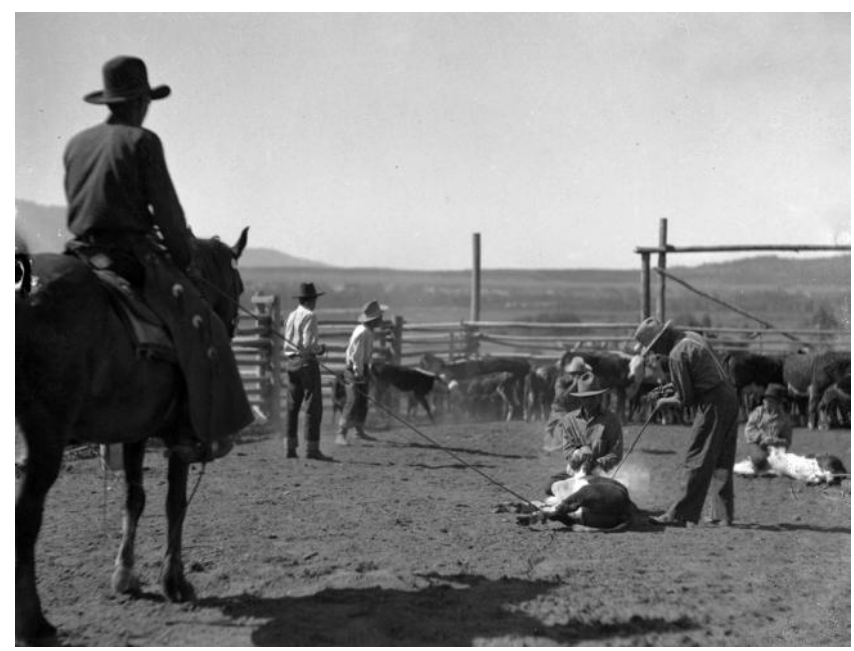

Figure 12. Branding cows (photo by Harrison R. Crandall, Grand Teton National Park archive).

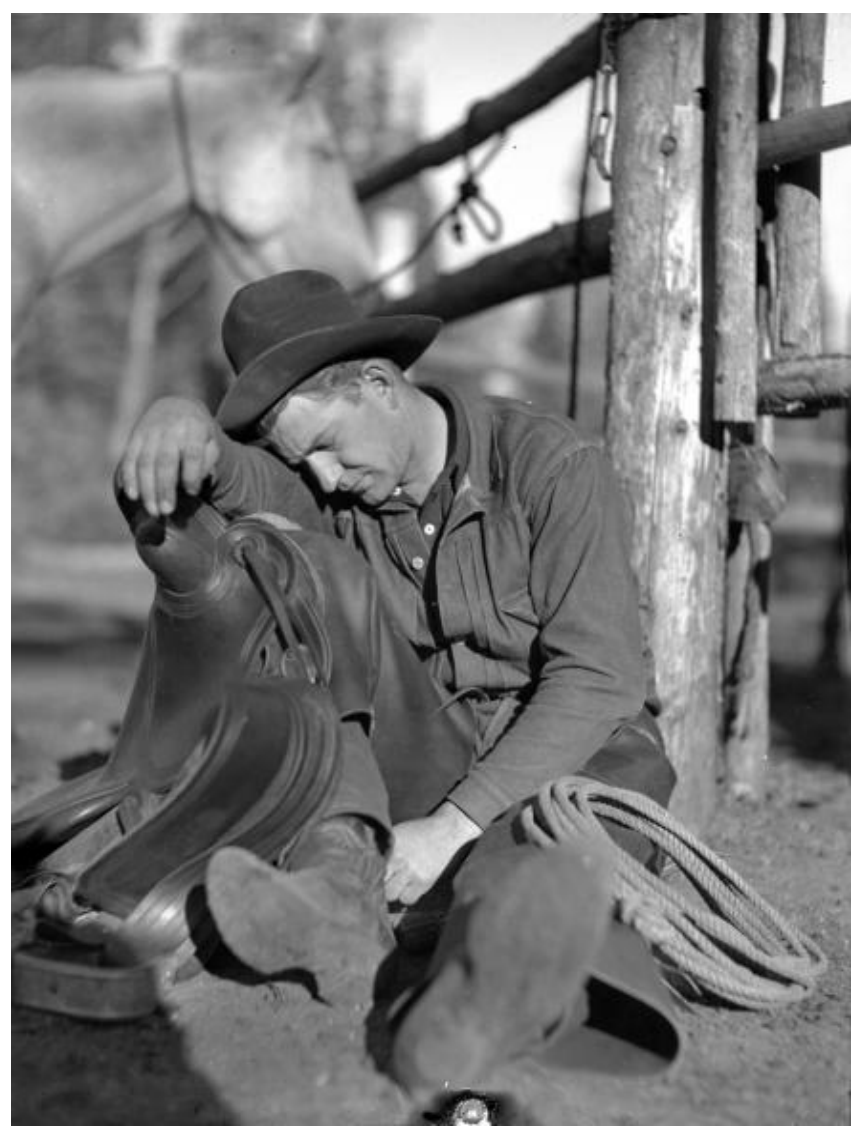

Figure 13. Cowboy at rest (photo by Harrison R. Crandall, Grand Teton National Park archive). 


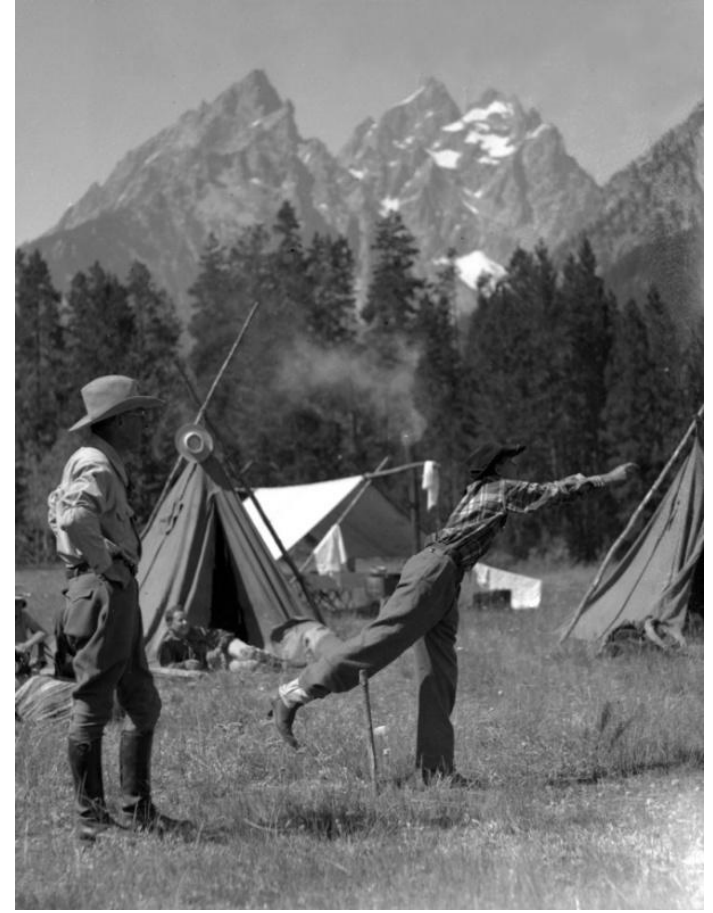

Figure 14. Kitty Lee and Powder River Jack (photo by Harrison R. Crandall, Grand Teton National Park archive).

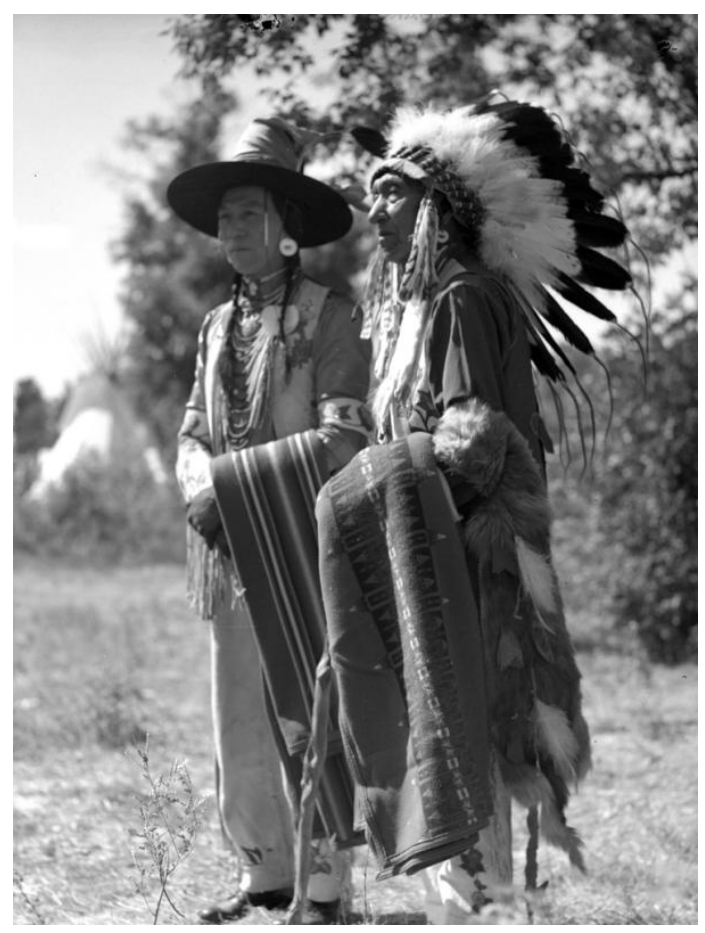

Figure 15. Native Americans at Powwow (photo by Harrison R. Crandall, Grand Teton National Park archive).

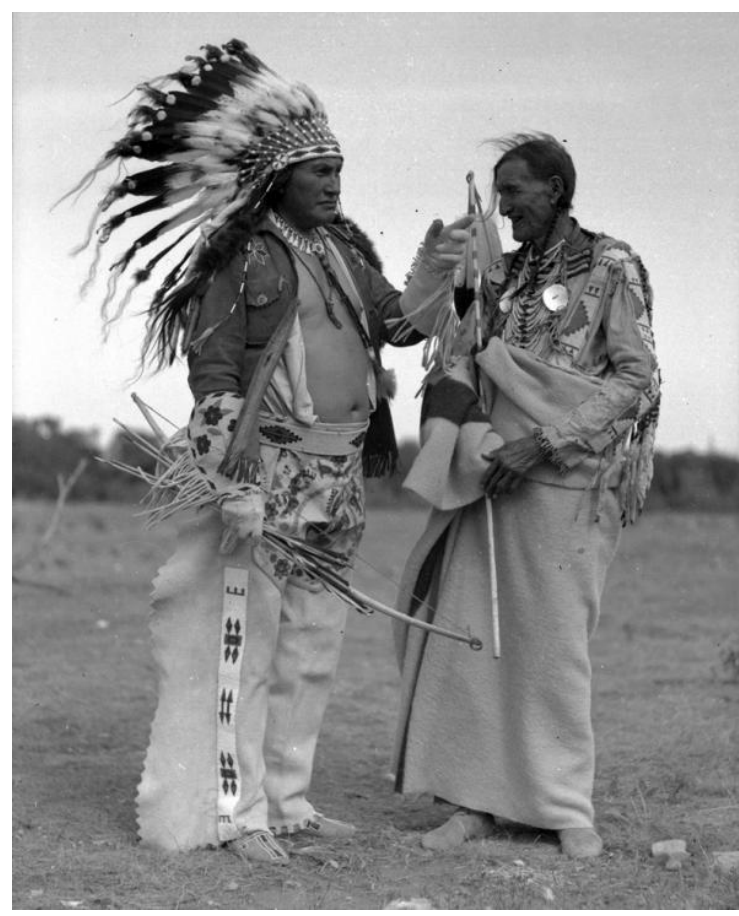

Figure 16. Bow training at powwow (photo by Harrison R. Crandall, Grand Teton National Park archive).

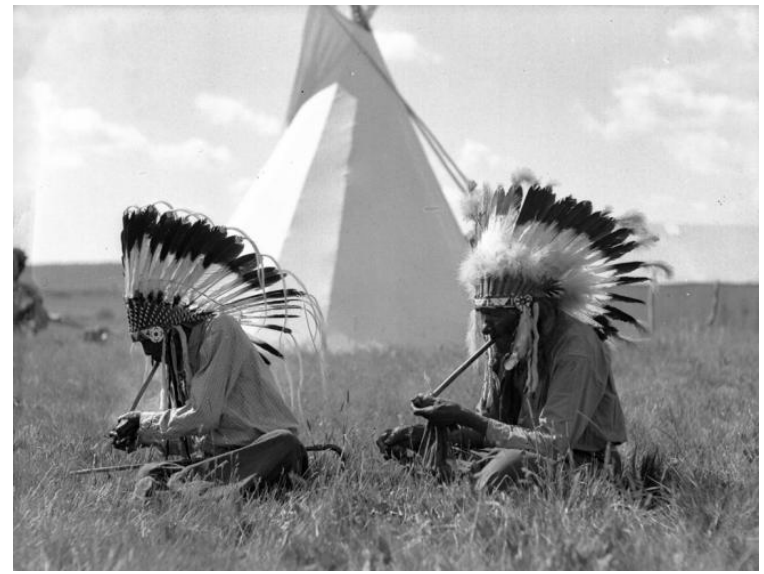

Figure 17. Powwow pipes (photo by Harrison R. Crandall, Grand Teton National Park archive). 


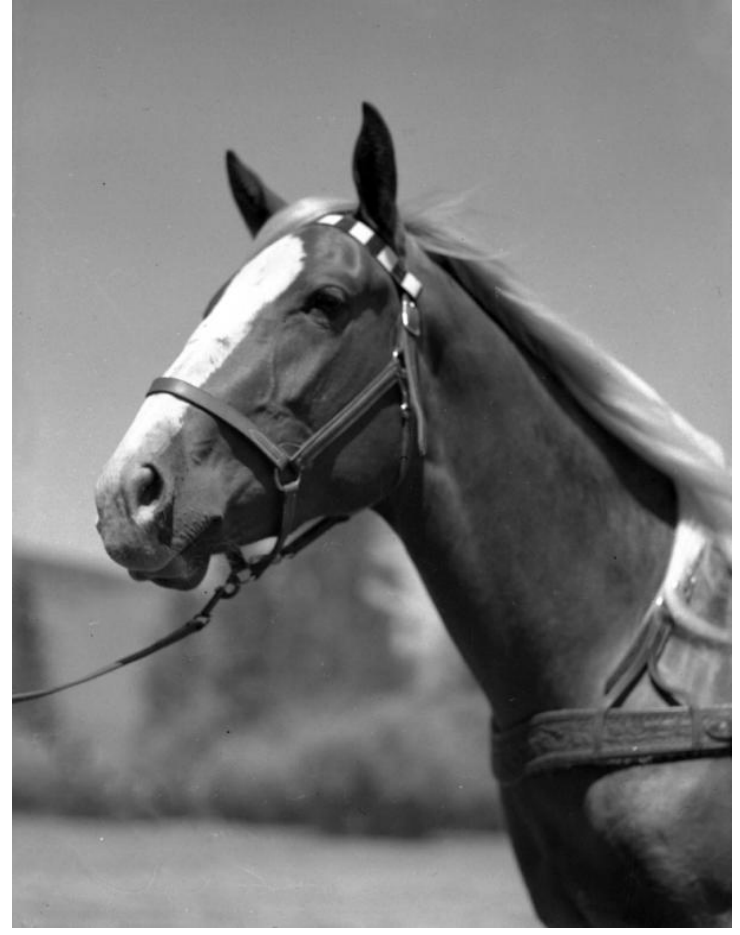

Figure 18. Horse portrait (photo by Harrison R. Crandall,Grand Teton National Park archive).

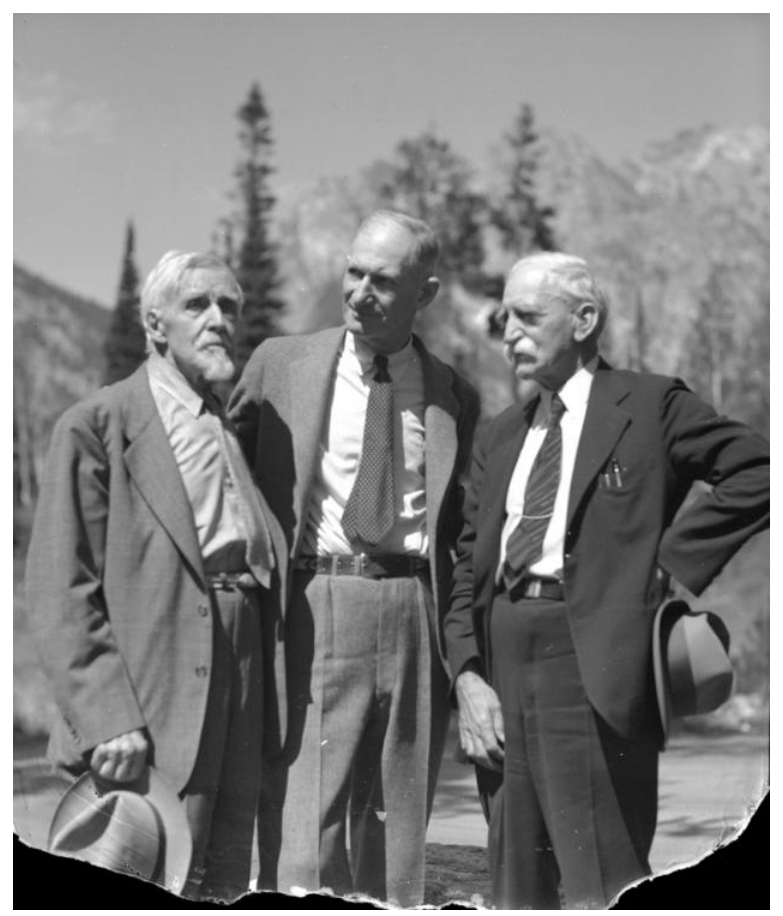

Figure 19. Meeting of dignitaries, including William Henry Jackson on left (photo by Harrison R. Crandall, Grand Teton National Park archive).

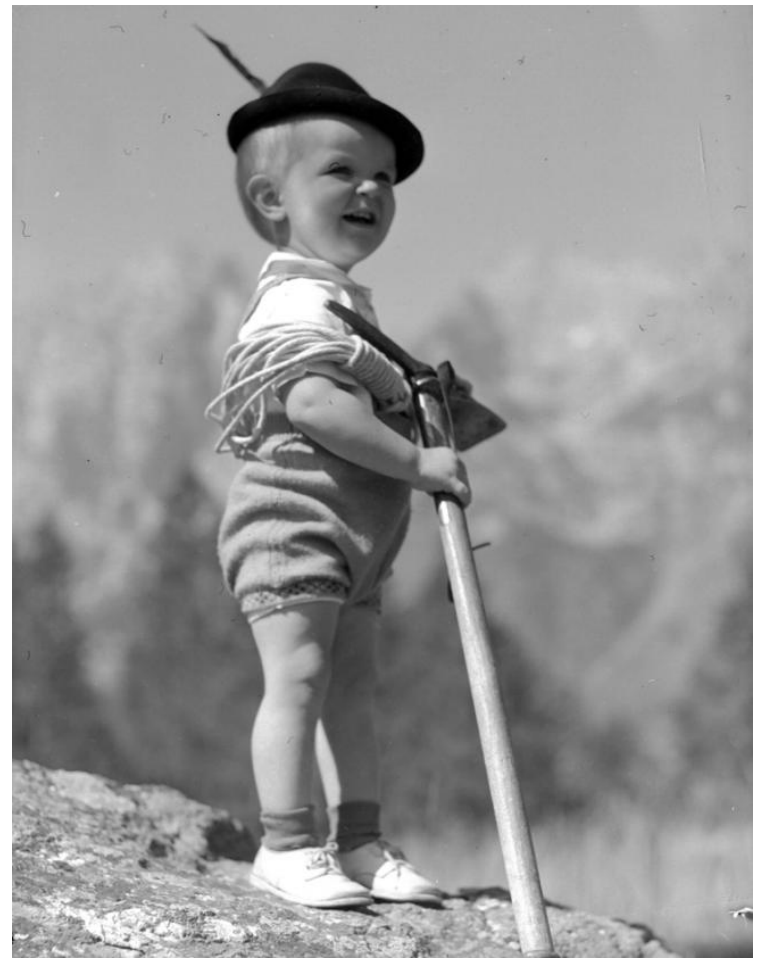

Figure 20. Little mountain climber (photo by Harrison R. Crandall, Grand Teton National Park archive). 